\title{
Employee Satisfaction towards Training Program With Reference To Butterfly Gandhimathi Home Appliances Ltd
}

\author{
Nandha Kumar, S. Praveen Kumar
}

\begin{abstract}
Most affiliations try delegate satisfaction, anyway not all achieve this target. That is the reason it's huge for $H R$ specialists to get some answers concerning the components that can extend delegate satisfaction, and how it fits into an association's general accomplishment. Every affiliation should offer getting ready to all of the delegates autonomous of their abilities and aptitudes.

This examination will characterize the factors of preparing and advancement and measure its job in worker fulfillment. It will improve techniques for preparing and distinguish the necessities of workers with these projects. This investigation will make methodologies of preparing and improvement so the students will utilize their capability to the most extreme degree conceivable and the associations will develop more with fulfilled clients. The reasons for this examination were to explore the desires and view of preparing quality between inn supervisors and workers, and to recommend suggestions for improving preparing quality and expanding preparing fulfillment, work fulfillment, and expectation to remain among representatives in the inn business.
\end{abstract}

Key Words: variables, job satisfaction, human resources

\section{INTRODUCTION}

Preparing and improvement projects are sorted out in any association to satisfy the prerequisite of representative advancement just as the accomplishment of the association as achievement of any association relies upon the worker's competencies.In preparing, the individuals who wish to adapt new aptitudes are called students and who train or give the abilities; information and skill are called mentors. The advantages of preparing and improvement are certain individual results just as positive hierarchical results. Higher execution, upper hand, higher authoritative duty and improving hierarchical maintenance are a portion of the advantages of preparing and advancement. Preparing and advancement projects give positive outcomes when arranged viably. Inadequate preparing turns into an exercise in futility and assets for the association and workers both. When we are evaluating preparing and advancement viability one of the most significant criteria is worker fulfillment. [1],[3],[5] Representatives' fulfillment with the association's Training and improvement practices can be normal just when the practices join workers' needs. In this way, in evaluating and

Revised Manuscript Received on July 22, 2019.

Nandha Kumar, Department of MBA, Bharath Institute of Higher Education and Research, Chennai, India.

Email: praveenkumar.mba@bharathuniv.ac.in

Dr. S. Praveen Kumar, Department of MBA, Bharath Institute of Higher

Education and Research, Chennai, India.

Email: praveenkumar.mba@bharathuniv.ac.in

improving the current practices, the degree of representatives' fulfillment with the practices is worth to consider. BPCL is an open area organization and it has a well-characterized HR division searching for the obligation of Training and advancement. [2],[4],[6]

Numerous researchers have referenced the need and significance of preparing and improvement in the associations.

Dale S. Shoreline characterizes preparing as 'the sorted out strategy by which individuals learn information as well as ability for a clear reason'. Preparing alludes to the educating and learning exercises carried on for the basic role of helping individuals from an association obtain and apply the information, aptitudes, capacities, and dispositions required by a specific occupation and association. [7], [9] ,[11]

In the present situation analysts have understood that preparation and improvement have turned into the need for the executives of association and its survival. Preparing is the way toward expanding the abilities of a worker for completing a specific employment. There are numerous kinds of preparing, for example, work pivot, work guidance, instructing that goes under hands on preparing and contextual investigation, pretend, mechanical visits that goes under off the activity preparing. Preparing is a methodicallly composed program to upgrade abilities of recently selected workers just as existing representatives required for employment necessities. Preparing is transient bundle which targets improving individual and gathering execution to increment hierarchical execution. It centers around information, conduct and frame of mind of representatives. Preparing mitigates the hole in genuine abilities and wanted aptitudes in representatives. Preparing can be at work and off the activity based on whether representatives get information at work spot or out

Preparing improves nature of workers. It gives extra aptitudes and information to work apparatus and to perform exercises. Wastage can be diminished. They can create most extreme yield with least assets. In this manner, efficiency can be improved. It expels wavering, dread and apprehension of representatives. Preparing builds up two path interchanges at work spot with bosses and associates. This improves execution and keep up agreeable relationship inside association. [8], [10],[12] It assumes a significant job in making a representative a contend individual. It gives better work opportunity, duty and pay. Along these lines, preparing builds up representative's character. Preparing has been found to connect with improving occupation

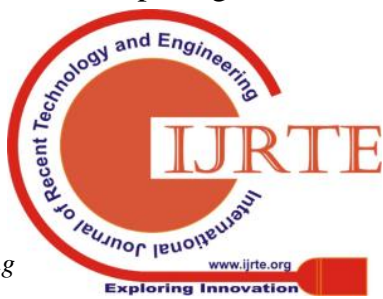


fulfillment and worker expectation to remain.

\section{OBJECTIVES}

\section{A. Primary}

- To study on employee satisfaction towards training program

\section{B. Secondary}

- To study the satisfaction level of the employees in training program

- To find out the productivity level of the employee from the training program

- To suggest the suitable measures for the training program in the organization

- To assess the employees perception towards training program in the organization[13], [15],[17]

\section{Need for the Study}

- To gain knowledge about the training process of the company.

- To focus on the employee satisfaction level towards training.

- To know about employee behavior before and after training.

- To find out the training process/strategy of the company.

- To find out the KSA (knowledge, Skills, Abilities) level of the employees.

\section{Scope for the Study}

- This report can be used for future references.

- The study may serve as a guide to the students.

- The study may benefit the organization in knowing their abilities and performance

\section{Limitations}

- Due to time constrain, the in dept detailed analysis of the employees were not possible.

- The sample size used for the survey is small.

- The strength of the company is high; hence it was not possible to draw each and every department's perception.

\section{RESEARCH METHODOLOGY}

\section{PRIMARY DATA COLLECTION:}

This study is based on the primary data. Questionnaires are the standardized form which is created and submitted to the respondents to get an idea about their satisfaction level towards training program conducted in the company.

Each questionnaire contained 12 questions from which the respondents are required to select the suitable options and a last question to express their point of view. Further the results that are gathered from these questionnaires are used to evaluate the employee satisfaction level. [14], [16],[18]

\section{A. Research Design}

Percentage analysis is applied to create tables/charts from the frequency distribution and represent the collected data for better understanding.

Chi square test is a statistic that is a sum of terms each of which is a quotient obtained by dividing the square of the difference between the observed and theoretical values of a quantity by the theoretical value. It has been implemented to analyze the significance between two statements (that is chosen particularly and the data iscollected from the questionnaire) to conclude the overall satisfaction level of employees and satisfaction towards productivity after attending the training program.

This information will be valuable to the organization to consider ways in order to gain more benefits from the training program they conduct. [19], [21],[23]

\section{B. Data Analysis}

Table 1: Table showing the satisfaction level of employees for the training provided.

\begin{tabular}{|l|l|l|}
\hline PARTICULARS & NO.OF. RESPONDENTS & PERCENTAGE \\
\hline Extremely satisfied & 25 & $50 \%$ \\
\hline Satisfied & 15 & $30 \%$ \\
\hline Dissatisfied & 5 & $10 \%$ \\
\hline Extremely dissatisfied & 5 & $10 \%$ \\
\hline
\end{tabular}

Analysis: From the table, it is proved that $50 \%$ of the respondents are extremely satisfied, $30 \%$ of the respondents are satisfied, $10 \%$ of the respondents are dissatisfied, the rest of the $10 \%$ are extremely dissatisfied.

Interpretation: Most of the employees are satisfied with their training programs offered.

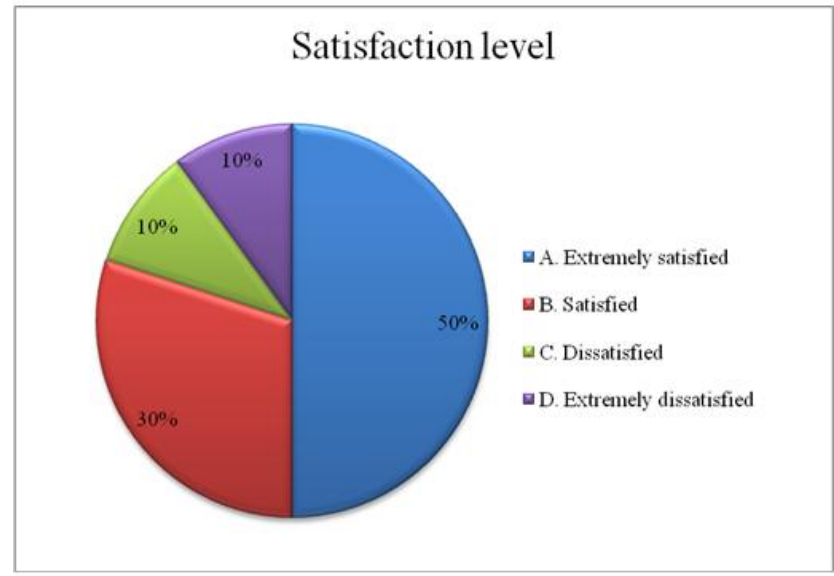

Figure 1: Satisfaction level of employees for the training provided.

TABLE 2: Table shows the result of the question on whether Employee's Qualification matches the Job Description.

\begin{tabular}{|l|l|l|}
\hline PARTICULARS & NO. OF. RESPONDENTS & PERCENTAGE \\
\hline Yes & 35 & $70 \%$ \\
\hline No & 15 & $30 \%$ \\
\hline
\end{tabular}


Figure 2: Question on whether Employee's Qualification matches the Job Description.

Analysis: From the data, it is clear that $70 \%$ of the employee's qualification matches their job description, where $30 \%$ of the employees have given negative results saying that their qualification does not match their job description.

Interpretation:_Around $70 \%$ of the respondents have matching qualification for their job description.

Table3: Table Showing the Increase In Productivity Level Of The Employees.

\begin{tabular}{|l|l|l|}
\hline PARTICULARS & NO.OF. RESPONDENTS & PERCENTAGE \\
\hline Yes & 32 & $64 \%$ \\
\hline No & 18 & $36 \%$ \\
\hline
\end{tabular}

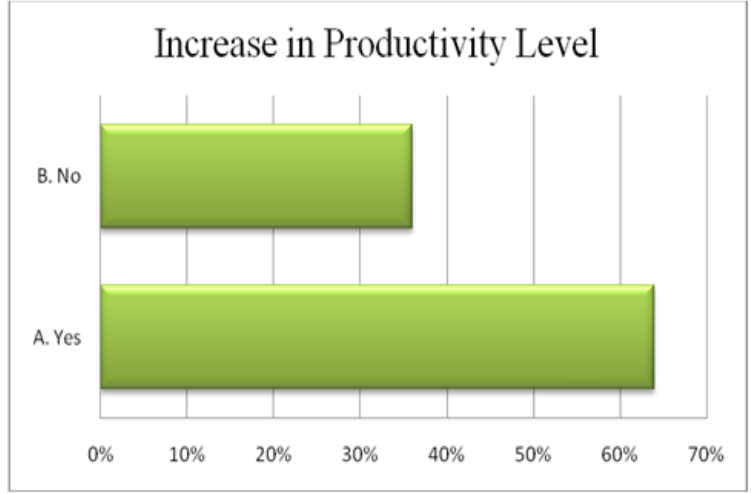

Figure3: The Increase in Productivity Level Of The Employees.

Analysis: From the data, $64 \%$ of the respondents have shown that there is an increase in their productivity level as a result of the training program offered by the company, whereas $36 \%$ of the respondents have shown that there is no increase in their productivity level, i.e. the remaining respondents seems to maintain a constant level of productivity.

Interpretation: Most of the employees are having the potential to increase their productivity level after attending the training program.

Table 4: The table showing the satisfaction level towards productivity

\begin{tabular}{|l|l|l|}
\hline PARTICULARS & NO.OF. RESPONDENTS & PERCENTAGE \\
\hline Extremely satisfied & 19 & $38 \%$ \\
\hline Satisfied & 13 & $26 \%$ \\
\hline Dissatisfied & 10 & $20 \%$ \\
\hline Extremely dissatisfied & 8 & $16 \%$ \\
\hline
\end{tabular}

Analysis: From the table, it is clearly stated that $38 \%$ of the employees are extremely satisfied with the increase in their productivity level whereas $26 \%$ of the employees are satisfied with their increased productivity level, $20 \%$ of the employees are dissatisfied and $16 \%$ of the employees are extremely dissatisfied with their productivity level.

Interpretation: More than $60 \%$ of the employees are satisfied with their increased productivity level after attending the training program.

\section{A. Chi Square Test}

To find the relationship between the overall satisfaction of the employees and the satisfaction towards the productivity level of the employees after attending the training program. With the help of the data collected from the questions 1 and 4 .

\section{TESTING OF HYPOTHESIS:}

A. NULL HYPOTHESIS $\left(\mathbf{H}_{\mathbf{0}}\right)$ : There is no significant difference between the overall employee satisfaction and the employee satisfaction towards productivity level.

B.ALTERNATE HYPOTHESIS $\left(\mathrm{H}_{1}\right)$ : There is a significant difference between the overall employee satisfaction and the employee satisfaction towards productivity level.

C.LEVEL OF SIGNIFICANCE: @5\%, $\alpha=0.05$

\section{TEST STATISTIC}

CHI SQUARE: $\mathbf{X}^{2}=\sum(\mathrm{O}-\mathrm{E})^{2} / \mathrm{E}$

(Where, $\mathrm{O}=$ observed frequency, $\mathrm{E}=$ expected frequency) $\mathrm{E}=\mathrm{RT} * \mathbf{C T} / \mathrm{GT}$

(Where, RT $=$ row total, $\mathrm{CT}=$ column total, $\mathrm{GT}=$ grand total)

\section{E. DEGREE OF FREEDOM: (r-1)(c-1)}

Table 5: Observed Frequency $(\mathrm{O})$

\begin{tabular}{|c|c|c|c|c|c|}
\hline $\begin{array}{l}\rightarrow \text { Overall } \\
\text { Employee } \\
\text { satisfactio }\end{array}$ & $\begin{array}{l}\text { Extremel } \\
\text { y } \\
\text { Satisfied }\end{array}$ & $\begin{array}{l}\text { Satisfie } \\
\text { d }\end{array}$ & $\begin{array}{l}\text { Dissatisfie } \\
\text { d }\end{array}$ & $\begin{array}{l}\text { Extremely } \\
\text { Dissatisfie } \\
\text { d }\end{array}$ & TOTAL \\
\hline \begin{tabular}{l}
\multicolumn{1}{c}{$\mathbf{n}$} \\
Satisfaction \\
towards \\
productivity \\
level
\end{tabular} & & & & & \\
\hline $\begin{array}{l}\text { Extremely } \\
\text { Satisfied }\end{array}$ & 10 & 9 & 0 & 0 & 19 \\
\hline Satisfied & 5 & 3 & 2 & 3 & 13 \\
\hline Dissatisfied & 5 & 3 & 1 & 1 & 10 \\
\hline $\begin{array}{l}\text { Extremely } \\
\text { Dissatisfied }\end{array}$ & 5 & 0 & 2 & 1 & 8 \\
\hline TOTAL & 25 & 15 & 5 & 5 & 50 \\
\hline
\end{tabular}


Table 6: Expected Frequency (E)

\begin{tabular}{|c|c|c|c|c|c|}
\hline \begin{tabular}{c|}
$\rightarrow$ Overall \\
Employee
\end{tabular} & \begin{tabular}{|l} 
Extremely \\
Satisfied
\end{tabular} & Satisfied & Dissatisfied & \begin{tabular}{|l|} 
Extremely \\
Dissatisfied
\end{tabular} & TOTAL \\
\hline $\begin{array}{l}\text { Satisfaction } \\
\text { towards } \\
\text { productivity } \\
\text { level }\end{array}$ & & & & & \\
\hline $\begin{array}{l}\text { Extregpely } \\
\text { Satisfied }\end{array}$ & 9.5 & 5.7 & 1.9 & \begin{tabular}{|l}
1.9 \\
\end{tabular} & 19 \\
\hline Satisfied & 6.5 & 3.9 & 1.3 & \begin{tabular}{|l|}
1.3 \\
\end{tabular} & 13 \\
\hline Dissatisfied & 5 & 3 & 1 & 1 & 10 \\
\hline $\begin{array}{l}\text { Extremely } \\
\text { Dissatisfied }\end{array}$ & 4 & 2.4 & 0.8 & 0.8 & 8 \\
\hline TOTAL & 25 & 15 & 5 & 5 & 50 \\
\hline
\end{tabular}

Table 3: Calculation

\begin{tabular}{|l|l|l|l|l|}
\hline $\begin{array}{l}\text { OBSERVED } \\
\text { FREQUENCY } \\
(\mathbf{O})\end{array}$ & $\begin{array}{l}\text { EXPECTED } \\
\text { FREQUENCY } \\
(\mathrm{E})\end{array}$ & $(\mathbf{O}-\mathrm{E})$ & $(\mathbf{O}-\mathrm{E})^{2}$ & $\mathbf{X}^{2}=\Sigma(\mathbf{O}-\mathrm{E})^{2} / \mathrm{E}$ \\
\hline 10 & 9.5 & 0.5 & 0.25 & 0.026315789 \\
\hline 5 & 6.5 & -1.5 & 2.25 & 0.346153846 \\
\hline 5 & 5 & 0 & 0 & 0 \\
\hline 5 & 4 & 1 & 1 & 0.25 \\
\hline 9 & 5.7 & 3.3 & 10.89 & 1.910526316 \\
\hline 3 & 3.9 & -0.9 & 0.81 & 0.207692308 \\
\hline 3 & 3 & 0 & 0 & 0 \\
\hline 0 & 2.4 & -2.4 & 5.76 & 2.4 \\
\hline 0 & 1.9 & -1.9 & 3.61 & 1.9 \\
\hline 2 & 1.3 & 0.7 & 0.49 & 0.376923077 \\
\hline 1 & 1 & 0 & 0 & 0 \\
\hline 2 & 0.8 & 1.2 & 1.44 & 1.8 \\
\hline 0 & 1.9 & -1.9 & 3.61 & 1.9 \\
\hline 3 & 1.3 & 1.7 & 2.89 & 2.223076923 \\
\hline 1 & 1 & 0 & 0 & 0 \\
\hline 1 & 0.8 & 0.2 & 0.04 & 0.05 \\
\hline & & & TOTAL & 13.39068826 \\
\hline
\end{tabular}

DEGREE OF FREEDOM: (r-1) (c-1)

$=(4-1)(4-1)$

$$
\begin{aligned}
& =(3)(3) \\
& =9
\end{aligned}
$$

\section{COMPARISON:}

Calculated value: 13.39068826 , Table value (at 9df): 16.919 $13.39068826<16.919$

The calculated value is less than table value (i.e. $\mathrm{CV}<\mathrm{TV}$ ), we accept $\mathrm{H}_{0}$ and reject $\mathrm{H}_{1}$.

Since CV is less than TV we accept the null hypothesis $\left(\mathrm{H}_{0}\right)$ that, there is no significant difference between the overall employee satisfaction and the employee satisfaction towards productivity level after attending the training program.

\section{V.RESULTS}

1. From the survey, most of the employees are extremely satisfied whereas the rest are lesser satisfied with their training programs conducted by the organization, some seems to find difficulty in coping up maybe because of some reasons like lack of attention, poor training or some other issues they deal with. [20], [22], [24]

2. Some of the employees find difficulty in getting along with the training and their actual job description, whereas most of the employees arecomfortable with it.

3. Most of the respondents are benefited from the training and are very determined to do their job. Even though workload is heavy or not they are ready to work.

4. Based on the datait is inferred that most of the employees agree to that their productivity level has been increased through the training program conducted, whereas some of the employees find that their level of productivity is the same.

5. The result of the satisfaction level towards the increase in productivity after attending the training programs is found to be higher than the average, only few employees are not satisfied towards the increase in productivity level after attending the training programs.

6. Employees are guided with realistic goals through training, which makes them achieve it during their career process.

7. Some of the employees are well equipped with their job resources (or) technology, where some are not equipped it may be due to their nature of work and their job description.

8. From the chi-square test it is analyzed and proved that the overall satisfaction level of the employees after attending the training program and their satisfaction towards productivity level (after the training program) remains constant.

9. The Training provided by the company over a particular period of time is sufficient for the employees to cope up with the work. The time gap between each training for the employees is maintained well. [25], [27], [29]

\section{DISCUSSIONS}

A change in the training method or a better training strategy may be adapted to bring more awareness of the training program between the employees, as the employee's perception towards training is less adequate.Training sessions should not be very long instead small and more frequent sessions. If the employees are subject to any doubts or questions during the program, they should be given first preferences in order to give the appropriate answers, as well as the employees should be efficiently guided with realistic goals to be achieved. This is to make employees more efficient and productive. [26], [28], [30]

The organization must take further steps in bringing out the importance of the training programs as it is the first step to productivity and brings organization effectiveness.Organizations should take care to increase the confidence of employees that they take care of them. This can be done by increasing the number of training and development programs both at managerial and non-managerial levels.Training and development programs should be able to create innovation and creativity in employees. Training and development programs in public relations and communication skills are recommended to the 
employees.

\section{CONCLUSION}

In this turbulent business environment where survival of the organizations have become tough focus of the organization is on competent employees. Organizations are focusing more on employees training and development. In this study,it is show that how the satisfaction level of employees with training and development practices in Butterfly Gandhimathi home appliances ltd has been interpreted.

As a result of the study,the training and development practices had positive impact on employee satisfaction. Employees were found to be highly satisfied with the variables training methods, training types, delivery and quality of training and development programs, training curriculum, and usefulness of training in enhancing their work performance, and performance and encouragement provided by trainer. Employees felt the need of changes in some areas of training and development like competent professionals, realistic goals etc. [31], [33]

The training provided by the company is more of "On the Job Training" such as Job Rotation, Near the Job training, case study etc which increased the KSA(knowledge, skill, ability) level of the employees.

Hence, finally it is concluded that more than $50 \%$ of the employees are satisfied and benefited from the training program offered by Butterfly Gandhimathi Appliances Limited. The overall productivity level has been increased leading to the organization's effectiveness.

\section{REFERENCES}

1) BharthVajan R., Ramachandran S.,Psychographic dimensions of training,2016,International Journal of Pharmacy and Technology,V-8,I-4,P-23727-23729

2) Balakrishnan P., Bharthvajan R.,A study on human resource planning in hospitals in Chennai City,2014,International Journal of Applied Engineering Research,V-9,I-22,P-7503-7507

3) Priyadarsini P., Bharthvajan R.,Role of emotional intelligence training programme in reducing the stress of the nurses,2014,International Journal of Applied Engineering Research,V-9,I-22,P-7411-7421

4) Kerinab Beenu G., Bharthvajan R.,Empirical analysis on the cosmetic buying behavior of young women in South India,2014,International Journal of Applied Engineering Research,V-9,I-22,P-7361-7366

5) Balakrishnan P., Bharthvajan R.,Whistling in the wind,2014,International Journal of Applied Engineering Research,V-9,I-22,P-7586-7593

6) Krishnan B., Peter M.,Health hazards of Indian Bpo employee-an alarming issue,2014,International Journal of Applied Engineering Research,V-9,I-22,P-7336-7341

7) Kerinab Beenu G.H., Peter M.,Role of insurance in economic development,2014,International Journal of Applied Engineering Research,V-9,I-22,P-7532-7539

8) Balakrishnan P., Peter M., Priyadarsini P.,Efficiency of safety measures for wellbeing of employees in manufacturing industry,2014,International Journal of Applied Engineering Research,V-9,I-22,P-7376-7382

9) Anbarasi M., Praveen Kumar S.,Online sales promotions of herbal products and its effectiveness towards tanisha.com,2019,Indian Journal of Public Health Research and Development,V-10,I-1,P-195-200

10) Anbarasi M., Praveen Kumar S., Various online marketing and promotions strategies to improve the validation towards the organic products in the pharmaceutical sectors,2019,Indian Journal of Public Health Research and Development,V-10,I-1,P-263-269

11) Loganathan R., Praveen Kumar S.,Grievance handling a key factor for solving issues of employees in an organization,2014,International Journal of Applied Engineering Research,V-9,I-22,P-7483-7491
12) Loganathan R., Praveen Kumar S.,Study on preference of private label brands in super and Hypermarkets, 2014,International Journal of Applied Engineering Research,V-9,I-22,P-7327-7335

13) Smitha M., Praveen Kumar S.,Understanding stress and its managementamong the nurses in Chennai city,2014,International Journal of Applied Engineering Research,V-9,I-22,P-7560-7565

14) Kerinab Beenu G.H., Praveen Kumar S.,A study on the investment behavior of Chennai investors in mutual fund schemes,2014,International Journal of Applied Engineering Research,V-9,I-22,P-7520-7525

15) Loganathan R., Praveen Kumar S.,Retention strategies key for organizational productivity,2014,International Journal of Applied Engineering Research,V-9,I-22,P-7443-7447

16) Pavithra J., Ganesan M., Brindha G.,State wise analysis of microfinance sector in India,2016,International Journal of Pharmacy and Technology,V-8,I-4,P-23417-23432

17) Pavithra J., Ganesan M.,A comparative study on microfinance in India and abroad,2016,International Journal of Applied Business and Economic Research,V-14,I-8,P-5471-5476

18) Pavithra J., Ganesan M.,A study on awareness and impact of micro-financial schemes,2016,International Journal of Applied Business and Economic Research,V-14,I-8,P-5449-5460

19) Senthilmurugan P., Pavithra J.,Consumer preference towards organised retailing with reference to Big Bazaar,2014,International Journal of Applied Engineering Research,V-9,I-22,P-7469-7475

20) Senthilmurugan P., Pavithra J.,Implication of social media marketing in growing healthcare industry,2014,International Journal of Applied Engineering Research,V-9,I-22,P-7448-7456

21) Loganathan R., Pavithra J.,Consumer perception towards private label brand over other brands in super markets and hypermarkets,2014,International Journal of Applied Engineering Research,V-9,I-22,P-7355-7360

22) Kerinab Beenu G., Pavithra J.,Tradeâ€"off between liquidity and profitability in logistics industry,2014,International Journal of Applied Engineering Research,V-9,I-22,P-7398-7401

23) Kerinab Beenu G., Pavithra J.,A study on the prospective consumerâ€ $\mathrm{TM}_{\mathrm{S}}$ perception towards utility cars in Chennai city,2014,International Journal of Applied Engineering Research,V-9,I-22,P-7526-7531

24) Pavithra J., Dilli Babu P., Ambuli T.V.,A study on budgetary control at Maruti Service Masters, Chennai,2014,International Journal of Applied Business and Economic Research,V-12,I-2,P-151-161

25) Pavithra J., Dilli Babu P., Ambuli T.V.,A study on customer satisfaction of retro Garments Pvt Ltd, Chennai,2014,International Journal of Applied Business and Economic Research,V-12,I-2,P-381-391

26) Kerinab Beenu G.H., Pavithra J., Senthilmurugan P.,A study on the influence of promotional activities for TATA ARIA among consumers in Chennai,2014,International Journal of Applied Engineering Research,V-9,I-22,P-7572-7578

27) Vijayaragavan S.P.,An investigative expert that's general FBG sensors,International Journal of Mechanical Engineering and Technology,V-8,I-8,PP-1500-1505,Y-2017

28) Vijayaragavan S.P.,Equalization routing protocol for Wi-Fi sensor strategy,International Journal of Mechanical Engineering and Technology,V-8,I-8,PP-1662-1666,Y-2017

29) Karthik B., Kiran Kumar T.V.U., Vijayaragavan P., Bharath Kumaran E.,Design of a digital PLL using 0.35 $\hat{\mathrm{I}}^{1} / 4 \mathrm{~m}$ CMOS technology,Middle East Journal of Scientific Research,V-18,I-12,PP-1803-1806,Y-2013

30) Kanniga E., Selvaramarathnam K., Sundararajan M.,Kandigital bike operating system,Middle - East Journal of Scientific Research,V

31) Jasmin M., Vigneshwaran T., Beulah Hemalatha S.,Design of power aware on chip embedded memory based FSM encoding in FPGA,International Journal of Applied Engineering Research,V-10,I-2,PP-4487-4496,Y-2015

32) Jasmin M.,Optimization techniques for low power VLSI circuits,Middle East Journal of Scientific Research,V-20,I-9,PP-1082-1087,Y-2014

33) Jasmin M., Vigneswaran T.,Fuzzy controller for error control of on - Chip communication,2017 International Conference on Algorithms, Methodology, Models and Applications in Emerging Technologies, ICAMMAET 2017,V-2017-January,I-,PP-1-5,Y-2017 
Employee Satisfaction Towards Training Program With Reference To Butterfly Gandhimathi Home Appliances Ltd

\section{AUTHORS PROFILE}

Nandha Kumar Research Scholar, Department of MBA, Bharath Institute of Higher Education and Research, Chennai, India.

Dr. S. Praveen Kumar Professor, Department of MBA, Bharath Institute of Higher Education and Research, Chennai, India. 